\title{
Community structure, picoplankton grazing and zooplankton control of heterotrophic nanoflagellates in a eutrophic reservoir during the summer phytoplankton maximum
}

\author{
Karel Šmek ${ }^{1, *}$, Petr Hartman ${ }^{1}$, Jiří Nedoma ${ }^{1}$, Jakob Pernthaler $^{2}$, \\ Doris Springmann ${ }^{3}$, Jaroslav Vrba ${ }^{1}$, Roland Psenner ${ }^{2}$
}

\author{
${ }^{1}$ Hydrobiological Institute of the Academy of Sciences of the Czech Republic, Na sádkách 7, CZ-37005 České Budějovice, \\ Czech Republic \\ ${ }^{2}$ Institute of Zoology and Limnology, University of Innsbruck, Technikerstrasse 25, A-6020 Innsbruck, Austria \\ ${ }^{3}$ Institute of Limnology, University of Konstanz, PO Box 5560, D-78434 Konstanz, Germany
}

\begin{abstract}
An intensive $5 \mathrm{wk}$ study was conducted to investigate the role of protists, especially heterotrophic nanoflagellates (HNF), in microbial food webs during the summer phytoplankton bloom in the epilimnion and metalimnion of the eutrophic Rimov reservoir (South Bohemia, Czech Republic). On average, protists consumed $\sim 90 \%$ of bacterial production in both layers. The community composition of HNF and the relative importance of different HNF groups as picoplankton consumers were determined. Small HNF $(<8 \mu \mathrm{m})$, as chrysomonads, bodonids and choanoflagellates, usually accounted for $<30 \%$ of total HNF biomass but numerically dominated the community in both layers. They consumed most of $(-70$ to $85 \%)$ the bacterioplankton as well as autotrophic picoplankton (APP, exclusively cyanobacteria) production in the reservoir, with the rest consumed by ciliates. Both ciliates and HNF had higher clearance rates on APP than on bactena and their grazing was likely responsible for a sharp decrease in APP abundance (from $3-4 \times 10^{5}$ to $<2 \times 10^{3} \mathrm{ml}^{-1}$ ) and a very constant size structure of bacterioplankton $u$ which short rods in the size class of 0.4 to $0.8 \mu \mathrm{m}$ constituted 55 to $80 \%$ of the total bacterial biomass in both layers. The proportion of HNF to total picoplankton biomass in the epilimnion indicated that the picoplankton biomass was sufficiently high to support HNF growth for most of the study. Uptake of picoplankton by less numerous, but larger, HNF (kathablepharids, Goniomonas sp., and Streptomonas sp.) was negligible, while their biomass, especially in the metalimnion, exceeded that of small HNF and the total biomass of picoplankton. This suggested that food items other than picoplankton were consumed to meet their carbon requirements. Analyzing potential bottom-up and top-down factors controlling HNF numbers and biomass, we did not find a tight relationship between HNF and the concentration of bacterid and chlorophyll. Variability of HNF abundance and biomass in the epilimnion could largely be explained by cladocerans or by pooled abundances of all potential crustacean consumers of HNF. In the metalimnion, the mean cell volume of HNF was positively linked to chlorophyll but negatively to the abundance of Cyclopidae and to the pooled abundances of Ceriodaphnia quadrangula and Diaphanosoma brachyurum.
\end{abstract}

KEY WORDS: Nanoflagellates · Community structure · Picoplanktivory - Bacterial production Food webs

\section{INTRODUCTION}

Small protists, especially heterotrophic nanoflagellates (HNF) and ciliates, are major consumers of picoplankton and nutrient regenerators; they serve as prey

•E-mail: ksimek@hbu.cas.cz for numerous micro- and metazooplankters in pelagic systems (e.g. Fenchel 1987, Sherr \& Sherr 1988, Sanders \& Wickham 1993). Principal top-down and bottom-up factors regulating HNF dynamics in freshwater aquatic systems have been intensively studied (e.g. Pace et al. 1990, Berninger et al. 1991, Jürgens 1994, Gasol et al. 1995). However, there have been 
very few studies on the trophic role and food-web relationships of this functionally diverse group of protists, labelled 'HNF', which contains species with different survival strategies and feeding ecology. Studies with a taxonomic insight at least at the functional level of the major components are required.

There is now increasing evidence from freshwater systems that HNF are numerically dominated by small, primarily bacterivorous forms (Sanders at al. 1989, Bennett et al. 1990, Weisse 1991). The process of 'bacterivory' has been largely defined as feeding on heterotrophic bacteria, but it can be considered to include (Sherr \& Sherr 1994) the consumption of both heterotrophic and autotrophic picoplankton (APP). The role of APP as a component of pelagic microbial food webs has been recently revised as well (Stockner 1988, Weisse 1993). However, it received little attention as a quantitatively and qualitatively important carbon source for protists, especially for HNF (e.g. Nagata 1988, Caron et al. 1991, Weisse 1993 and references therein). On the other hand, frequent observations of larger forms of HNF within natural communities (Mathes \& Arndt 1994), constituting a major proportion of HNF biomass, exceeding even the biomass of picoplankton, indicate that along with bacterivory other feeding modes are also likely of importance for some forms of planktonic HNF (Sanders 1991).

Protists, both HNF and ciliates, are very important consumers of both picoplankton and phytoplankton (Sherr \& Sherr 1994), which implies that pelagic protozoa have very different physiologies, survival strategies, and feeding modes (Fenchel 1987, Sanders 1991). However, there are only a few comparative studies on protists combining a wide range of both taxonomic and ecological approaches (Finlay et al. 1988, Sanders et al. 1989, Bennett et al. 1990, Simek et al. 1995)

As the doubling times of protozoa and other microorganisms in meso- and eutrophic waters are usually on the order of 1 to $4 \mathrm{~d}$, studies with high sampling frequency are required to elucidate the functional interactions within microbial food webs. The objective of this study was to assess the role of HNF communities at the highest achievable taxonomic level in the eutrophic Rímov reservoir during the summer phytoplankton peak. Whereas detailed information on the particular role of different ciliate taxa have been given in Simek et al. (1995), we report here on: (1) community structure and grazing rates of separate groups of HNF on bacteria and picocyanobacteria, and the role of HNF in controlling picoplankton population in the epilimnion and metalimnion of the reservoir; (2) the importance of picoplankton in the diet of various HNF taxa; and (3) factors of bottom-up and top-down control of HNF.

\section{MATERIALS AND METHODS}

Study site and sampling scheme. From 16 August to 23 September 1993, water samples were collected 3 times a week between 08:30 and 09:30 h from the eutrophic Kimov reservoir (South Bohemia, Czech Republic). The study site was located at the deepest point of the reservoir about $250 \mathrm{~m}$ from the dam. Samples were taken with a 2 I Friedinger sampler from 2 layers: the epilimnion (a mixed sample from $0.5,1$, and $1.5 \mathrm{~m}$ ) and the metalimnion (a mixed sample from the thermocline and from $0.5 \mathrm{~m}$ above and below this depth). A detailed description of the sampling procedure is given in Simek et al. (1995). From a final volume of 421 collected from the epilimnion and metalimnion, respectively, 2 l of the mixed sample was used for further phytoplankton and microzooplankton analyses. The remaining $40 \mathrm{l}$ of water was filtered through a $100 \mu \mathrm{m}$ plankton net to concentrate and remove zooplankton $>100 \mu \mathrm{m}$

Bacterial abundance and biomass. Subsamples were fixed with formaldehyde ( $2 \%$ final conc.), stained with DAPI (final conc. $0.2 \% \mathrm{wt} / \mathrm{vol}$ ) and enumerated by epifluorescence microscopy (Olympus BH2). Between 400 and 600 bacteria were sized by an interactive image analysis system (Lucia, Laboratory Imaging, Prague, Czech Republic). For further details see Psenner (1993) and Simek et al. (1995). Bacterial biomass was calculated according to the allometric relationship between cell volume and carbon content given by Norland (1993). As the variation of bacterial width was often below the minimal size differences reliably detectable by image analysis and, moreover, had little variability, we chose the variation in cell length to subdivide bacterioplankton into 7 size classes at $0.4 \mu \mathrm{m}$ intervals (for the treatment used see Pernthaler et al. 1996a).

Bacterial production. Bacterial production was measured via thymidine incorporation (BP-thy) with the method modified from Riemann \& Sondergaard (1986); for details see Simek et al. (1995). To determine empirical conversion factors (ECF) between thymidine incorporation rate and bacterial cell production rate, replicate $750 \mathrm{ml}$ subsamples of water filtered through $1 \mu \mathrm{m}$ filters (Poretics) were incubated for $24 \mathrm{~h}$ in the dark at in situ temperature. To avoid a possible breakdown of algal cells during the filtration procedure, only a gentle vacuum was applied. The bacterial cell production rate (BP-num) was calculated from the slope of the increase of $\ln$ bacterial abundance over time $(0,12,24 \mathrm{~h})$. Only samples in which no HNF were observed during and after the incubation were taken into account. The average ECF

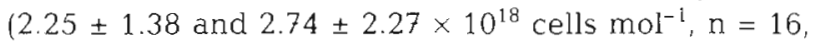
for the epilimnion and metalimnion, respectively) were used for calculations 
Picocyanobacteria abundance. Among autotrophic picoplankton (APP), only picocyanobacteria dominated, especially Synechococcus-like species (mean

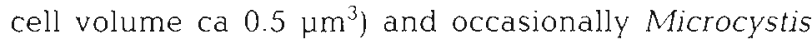
incerta of similar size. The latter species was partly floc forming; samples were therefore sonicated for $1 \mathrm{~min}$ (Ultrasonic Homogenizer 4710, Cole Palmer Instruments Co., Chicago, USA, set at 1) before counting APP, using the autofluorescence of phycobiliproteins for cell detection. The epilimnion and metalimnion APP were sized only twice during the course of the study using a fine scale eyepiece micrometer. A conversion factor of $200 \mathrm{fg}$ carbon $\mu^{-3}$ was assumed (Weisse 1993).

Protistan grazing and abundance. Two kinds of prey were used to measure protistan grazing upon picoplankton: fluorescently labelled bacterioplankton (FLB) and fluorescently labelled Synechococcus-like cyanobacteria (FLC) prepared according to the protocol of Sherr \& Sherr (1993). For details of the concentration procedures used for reservoir bacterioplankton and a Synechococcus-like species (mean cell volume \pm SD. $0.48 \pm 0.23 \mu \mathrm{m}^{3}$ ) see Šimek \& Straškrabová (1992) and Simek et al. (1995), respectively.

We determined protistan grazing impacts on bacterioplankton and A.PP in short-time FLB or FLC direct uptake experiments according to Šimek et al. (1995). Flagellate and ciliate uptake rates were determined in the same treatment, but separately for the 2 different tracers used, FLB and FLC. Tracer amounts of FLB accounted for 5 to $15 \%$ of natural bacterial abundances. The FLC addition constituted generally 10 to $25 \%$ of total APP abundance; however, at the beginning of September, when APP abundances had declined to $\sim 2 \times 10^{4} \mathrm{ml}^{-1}$, this was up to $40 \%$. For the rest of the experimental period APP abundances were too low for the tracer technique. For protistan enumeration and tracer ingestion determinations, $30 \mathrm{ml} \mathrm{sub-}$ samples were taken $0,3,6,10,20$, and 30 min after tracer addition and preserved according to Sherr \& Sherr (1993, for details see Simek et al. 1995).

We determined flagellate and ciliate grazing rates in subsamples from time series from 10 to 30 and 3 to 10 min, respectively. Samples from time zero were also inspected to avoid a potential bias due to attachment of non-ingested tracers on protistan surfaces. Within $24 \mathrm{~h}$ after fixation, $5 \mathrm{ml}$ (flagellates) or 20 to $30 \mathrm{ml}$ (ciliates) subsamples were stained with DAPI, filtered through $1 \mu \mathrm{m}$ black Poretics filters, and inspected via epifluorescence microscopy. Only flagellate individuals without plastids (checked for chl a fluorescence) were included in the counts of HNF. To estimate total protistan grazing rate (TPGR), we multiplied average uptake rates of HNF and ciliates by their total in situ abundances. For the 3 most abundant, relatively easily dis- tinguishable groups of HNF, i.e. small Spumella-like chrysomonads, bodonids and choanoflagellates, we determined tentatively their group-specific grazing rates on bacteria. A comparison of clearance rates on FLB and FLC was used to calculate relative selectivity by HNF for or against one of these 2 prey types.

Biomass and community structure of HNF. Geometrical approximations (prolate spheroids) were used to determine HNF mean cell volumes based on measurements of cell length and width (by an ocular micrometer) of at least 50 individuals per sample. For biomass estimations we assumed a conversion factor of $220 \mathrm{fg} \mathrm{C}$ $\mu \mathrm{m}^{-3}$ (Børsheim \& Bratbak 1987). A rough evaluation of HNF community structure was attempted 4 times combining the following approaches: (1) DAPI-stained samples in epifluorescence microscopy, (2) live sample observation, (3) protargol staining (Skibbe 1994, for details see Simek et al. 1995), and (4) scanning electron microscopy according to a slightly modified method of Marchant (1972). Criteria for grouping HNF into different taxonomic categories were: cell size and shape; size, position, and form of nuclei; number, position, and length of flagella; lack/expression of internal/ external cell organelles such as flagella, collar, kinetoplasts, vacuoles, etc. Since protargol staining and live sample observation were always applied in parallel with fluorescence microscopy, we were able to group most of the HNF into taxonomic units at the level of an order or family and, occasionally, even genus. Moreover, some of the dominant HNF species in the reservoir have been isolated and identified, so we used these reference cultures in both protargol-stained and fluorescence microscopy to confirm our determinations. Using the above approaches, however, usually between 15 to $20 \%$ of the inspected HNF could not be identified. Generally, we based our identifications on the publication of Patterson \& Larsen (1991) and references therein.

Disappearance of labelled cells. To evaluate the time-integrated grazing impact of all bacterivores $<100 \mu \mathrm{m}$ (i.e. mostly protists and small rotifers), $750 \mathrm{ml}$ of $100 \mu \mathrm{m}$ prescreened subsamples was incubated for $24 \mathrm{~h}$ in the dark at in situ temperature with a FLB addition constituting 3 to $6 \%$ of bacterial abundance. Subsamples $(20 \mathrm{ml})$ for quantifying labelled (FLB) and natural bacterial cells were taken at times 0,12 , and $24 \mathrm{~h}$. To calculate the rate of cell disappearance (FLB-disap) we used a linear model which also takes into account changes in natural bacterial abundances (Salat \& Marrasé 1994).

Zooplankton. Zooplankton $>100 \mu \mathrm{m}$ were concentrated from $40 \mathrm{l}$ (see above), preserved in $4 \%$ formaldehyde (final conc.) and quantified by direct microscopic counting of several subsamples (McCauley 1984). Rotifers were enumerated separately from un- 

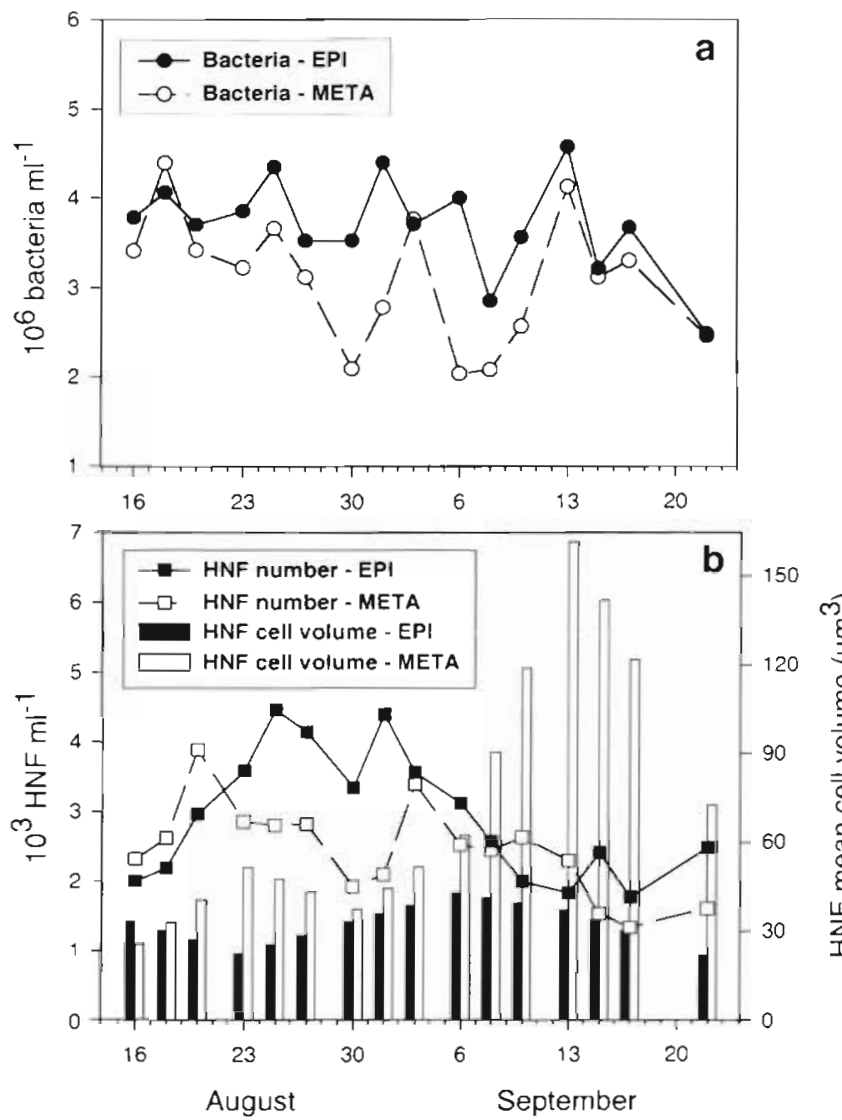

Fig. 1. (a) Bacterial abundance and (b) abundance and mean cell volume of heterotrophic nanoflagellates (HNF) in the epilimnion (EPI) and metalimnion (META), August-September 1.993

screened water as follows: samples (1 l) were preserved with acid Lugol's solution ( $1 \%$ final conc.) and, after sedimentation, postfixed with Bouin's fixative (5\% final conc.) added into the 10 -fold concentrated samples. The concentrated subsamples $(5 \mathrm{ml})$ were filtered onto nitrocellulose membrane filters (Synpor 1. $4 \mu \mathrm{m}$ pore size, $10 \mathrm{~mm}$ diam.; Barvy Laky, Czech Republic) and stained with carbolerythrosine (Sorokin \& Overbeck 1972). The whole filter area was inspected.

\section{RESULTS}

\section{Characteristics of bacterial and protistan abundances and cell volumes}

During the study period, water temperatures in the epilimnion and metalimnion varied between 15.3 and $22.2^{\circ} \mathrm{C}$, and 13.8 and $20.2^{\circ} \mathrm{C}$, respectively. The ranges of bacterial abundances (Fig. 1), mean cell volumes, and the corresponding mean carbon content per cell were similar in the epilimnion $\left(2.47\right.$ to $4.40 \times 10^{6}$ cells $\mathrm{ml}^{-1}, 0.039$ to $0.066 \mathrm{~mm}^{3}, 11$ to $15 \mathrm{fg} \mathrm{C}$ cell-1) and the metalimnion $\left(2.03\right.$ to $4.40 \times 10^{6}$ cells $\mathrm{ml}^{-1}, 0.034$ to $0.048 \mathrm{\mu m}^{3}, 10$ to $13 \mathrm{fg} \mathrm{C} \mathrm{cell}^{-1}$ ); Ior details see Simek et al. $(1995,1996)$. Cells between 0.4 and $0.8 \mu \mathrm{m}$ length accounted for 55 to $80 \%$ of the total bacterial biomass throughout the study (Fig. 2). Cells $<0.4 \mu \mathrm{m}$ and those between 0.8 and $1.2 \mu \mathrm{m}$ length constituted together another $\sim 10$ to $28 \%$ of total bacterial biomass, while the cells $>1.2 \mu \mathrm{m}$ length were generally of minor importance.

HNF abundances ranged similarly in both layers, between 1.4 and $4.5 \times 10^{3} \mathrm{ml}^{-1}$, except for the last week of August with their remarkably higher numbers in the epilimnion (Fig. 1). While the mean cell volume of preserved HNF in the epilimnion was between 19 and $39 \mu^{3}$, it sharply increased (up to $170 \mu \mathrm{m}^{3}$ ) in the
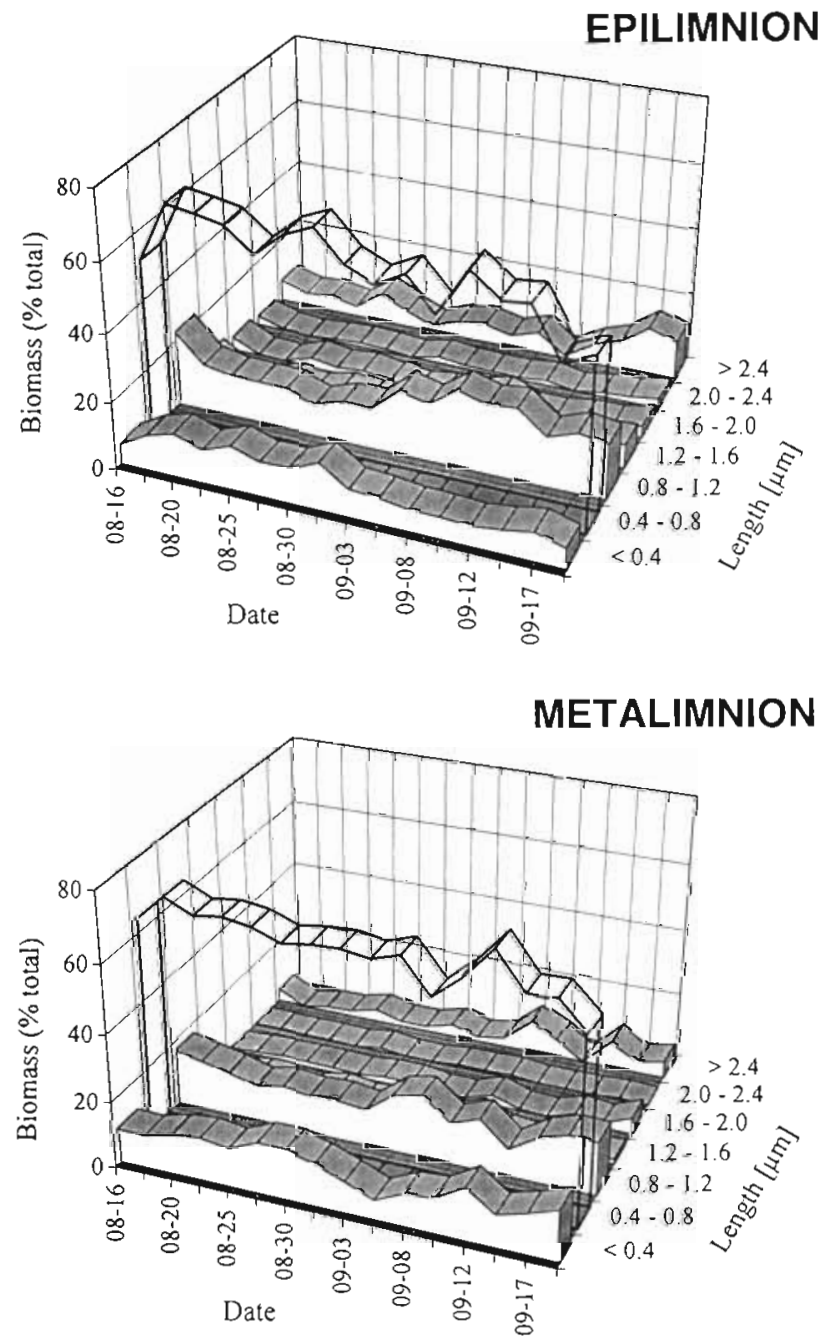

Fig. 2. Distribution of bacterial biomass ( $\%$ of total bacterial organic carbon) in different size classes (cell length) in the epilimnion and metalimnion, August-September 1993 
Fig. 3. Bacterial production measured via thymidine incorporation rate (BP-thy) and protozoan grazing (direct FLB uptake rate) divided into flagellate and ciliate bacterivory (left panels), and bacterial cell production rate (BP-num) and cell disappearance rate (FLB-disap, right panels) in the epilimnion (top) and metalimnion (bottom), August-September 1993
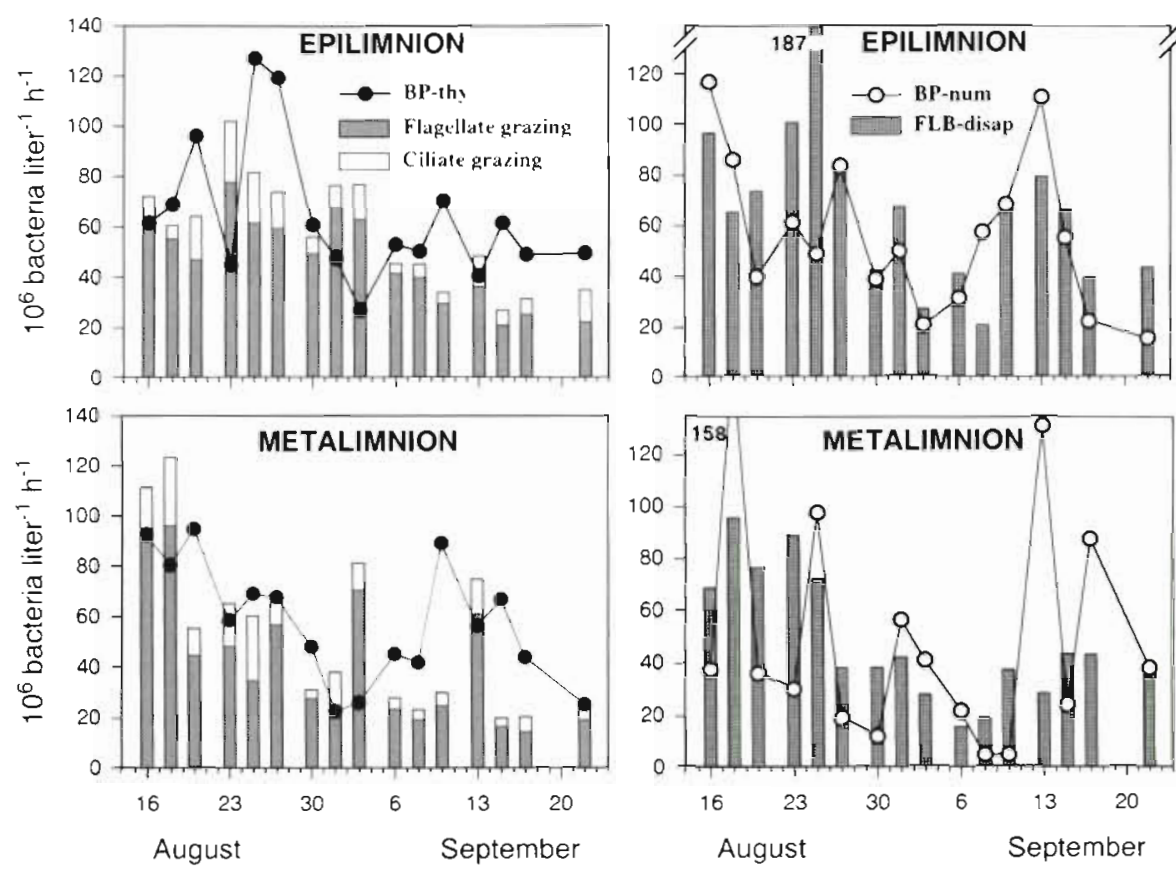

metalimnion during the second half of the study in parallel with a rising phytoplankton biomass (data not shown). Numbers of ciliates ranged from 6 to 55 cells $\mathrm{ml}^{-1}$ and from 13 to 70 cells $\mathrm{ml}^{-1}$ in the epilimnion and metalimnion, respectively. For a detailed description of phytoplankton and ciliate dynamics and species compositions see Simek et al. (1995).

\section{Comparison of bacterioplankton production and consumption}

To compare bacterioplankton production and consumption by protists, we used 2 different approaches. The first one was based on a short-term incubation of samples (thymidine uptake assay, BP-thy, vs total protozoan grazing rate, TPGR, measured via direct FLB uptake) whereas the second one followed changes in bacterial cell number (BP-num) versus FLB disappearance rate (FLB-disap), integrated over 24 h incubation.

Bacterioplankton production and grazing rates on bacteria (Fig. 3) showed different time courses (independent of the approach we used), but a very similar range of rates. On average, $91 \%$ of bacterial production in the epilimnion and $92 \%$ in the metalimnion was consumed by protozoa (Table 1). HNF accounted, on average, for 82 and $79 \%$ of the total protozoan grazing in the epilimnion and metalimnion, respectively. The role of ciliates (Fig. 3) has already been reported in detail by Šmek et al. (1995).

The estimates based on $24 \mathrm{~h}$ incubations showed slightly higher rates of bacterial consumption by bacterivores $<100 \mu \mathrm{m}$ compared to bacterial cell production (Table 1). Both short-term and $24 \mathrm{~h}$ incubations yielded very similar means both for bacterioplankton production and its consumption (cf. Fig. 3, Table 1). On the other hand, there was very little coincidence in the time courses of the corresponding parameters as evidenced by weak (TPGR vs FLB-disap in the epilimnion and in the pooled data) or insignificant correlations (BP-thy vs BP-num in both layers and in the pooled data; Table 2). BP-num was significantly positively linked to bacterial numbers for all but the epilimnion data set, and to FLB-disap for all but the metalimnion data set. TPGR was significantly and positively correlated with abundances of bacteria and HNF in all 3

Table 1. Comparison of parameters (mean $\pm \mathrm{SD}, \mathrm{n}=16$ ) for bacterial production and consumption rates, August-September 1993

\begin{tabular}{|lcc|}
\hline & $\begin{array}{c}\text { Epilimnion } \\
\left.\left(10^{6} \text { bacteria }\right]^{-1} \mathrm{~h}^{-1}\right)\end{array}$ & $\begin{array}{c}\text { Metalimnion } \\
\left(10^{6} \text { bacteria } \mathrm{l}^{-1} \mathrm{~h}^{-1}\right)\end{array}$ \\
\hline Bacterial production based on thymidine incorporation rate & $64.0 \pm 26.7$ & $58.0 \pm 23.9$ \\
Total protozoan grazing rate on bacteria & $58.1 \pm 20.7$ & $53.3 \pm 31.3$ \\
Bacterial production based on changes in cell numbers & $56.4 \pm 29.4$ & $51.7 \pm 43.8$ \\
Disappearance rate of fluorescently labelled bacteria & $65.7 \pm 38.4$ & $54.3 \pm 26.3$ \\
\hline
\end{tabular}


Table 2. Spearman rank correlations of HNF and bacterial abundances and parameters of bacterial production and consumption, August-September 1993 ( $n=16$ for the epi- and metalimnion, $n=32$ for the pooled sample). Epi: epilımnion; Meta: metalimnion; All: pooled data from both layers; HNF: total abundance of heterotrophic nanoflagellates; Bac: bacterial abundance; BP-thy: bacterial production based on thymidine incorporation rate, BP-num: bacterial production based on changes in cell numbers; TPGR: total protozoan grazing rate on bacteria; FLB-disap: FLB disappearance rate ${ }^{*} p<0.05_{i}{ }^{\cdots} p<0.01 ; \cdots p<0.001$

\begin{tabular}{|c|c|c|c|c|c|c|}
\hline & & HNF & $\mathrm{Bac}$ & BP-thy & BP-num & TPGR \\
\hline $\mathrm{Bac}$ & $\begin{array}{l}\text { All } \\
\text { Epi } \\
\text { Meta }\end{array}$ & $\begin{array}{l}0.312 \\
0.146 \\
0.344\end{array}$ & & & & \\
\hline BP-thy & $\begin{array}{l}\text { All } \\
\text { Epi } \\
\text { Meta }\end{array}$ & $\begin{array}{l}0.290 \\
0.109 \\
0.427\end{array}$ & $\begin{array}{r}0.187 \\
-0.156 \\
0.397\end{array}$ & & & \\
\hline BP-num & $\begin{array}{l}\text { All } \\
\text { Epi } \\
\text { Meta }\end{array}$ & $\begin{array}{l}-0.088 \\
-0.247 \\
-0.087\end{array}$ & $\begin{array}{l}0.628 \cdots \\
0.297 \\
0.775 \cdots\end{array}$ & $\begin{array}{r}0.132 \\
0.265 \\
-0.046\end{array}$ & & \\
\hline TPGR & $\begin{array}{l}\text { All } \\
\text { Epi } \\
\text { Meta }\end{array}$ & $\begin{array}{l}0.614^{\cdots} \cdots \\
0.721^{\circ} \\
0.559^{\circ}\end{array}$ & $\begin{array}{l}0.686^{\cdots} \\
0.533^{\circ} \\
0.712^{\circ}\end{array}$ & $\begin{array}{r}0.278 \\
-0.003 \\
0.379\end{array}$ & $\begin{array}{l}0.369^{\circ} \\
0.144 \\
0.454\end{array}$ & \\
\hline FLB-disap & $\begin{array}{l}\text { All } \\
\text { Epi } \\
\text { Meta }\end{array}$ & $\begin{array}{l}0.222 \\
0.252 \\
0.156\end{array}$ & $\begin{array}{l}0.514^{\circ} \\
0.436^{\circ} \\
0.506^{\circ}\end{array}$ & $\begin{array}{l}0.518^{\circ} \\
0.382 \\
0.592\end{array}$ & $\begin{array}{l}0.495^{\circ} \\
0.553^{\circ} \\
0.373^{\circ}\end{array}$ & $\begin{array}{l}0.454^{\circ} \\
0.538^{\circ} \\
0.309^{\circ}\end{array}$ \\
\hline
\end{tabular}

data sets and with FLB-disap in all but the metalimnion data set. FLB-disap was positively related to bacterial abundance and BP-thy for all but the epilimnion data set, however, no significant relation was found with abundance of HNF (Table 2, Fig. 3)

We also did not find any significant correlation between ciliate abundance or biomass versus the parameters of bacterial production and protistan bacterivory listed in Table 2 .

\section{Community structure and grazing of heterotrophic nanoflagellates on picoplankton}

HNF appeared to be a very diverse group of organisms belonging to different taxa (Table 3) with distinct efficiencies as picoplanktivores (see below). We made a rough evaluation of the HNF community structure on a group or genus level on 4 separate occasions (Fig. 4). On average, 3 groups of HNF of the smallest cell size (mostly 3 to $8 \mu \mathrm{m}$ length), chrysomonads, bodonids, and choanoflagellates, accounted for about $70 \%(\sim 49,11$, and $10 \%$, respectively) of the total HNF abundance in both the ept-and metalimnion. Owing to a high cell-specific grazing rate on picoplankton (Table 3), these HNF groups were clearly the most important picoplanktivores in the reservoir. In terms of biomass, however, they accounted only for 10 to $25 \%$ of the total HNF (except for $>30 \%$ on 16 August in the metalimnion).

Other HNF taxa of larger cell volume, i.e. Kathablepharis sp., Goniomonas sp., Cercomonas sp., and Streptomonas sp. (Table 3), showed cell-specific grazing rates on bacteria which were lower by more than 1 order of magnitude. We did not present these grazing rates due to their very high statistical uncertainty, as

Table 3. Cell-specific grazing rates on bacteria for the 3 most abundant bactenvorous flagellate groups, mean cell volumes and community structure of heterotrophic nanoflagellates on group or genus level (based on evaluation of 4 sampling dates; for details see Fig. 4). Epi: epilimnion; Meta: metalimnion

\begin{tabular}{|c|c|c|c|c|c|c|}
\hline \multirow[t]{2}{*}{ Flagellate group } & \multicolumn{2}{|c|}{$\begin{array}{l}\text { Grazing rate } \\
\text { (bact. flag. }{ }^{-1} \mathrm{~h}^{-1} \text { ) }\end{array}$} & \multicolumn{2}{|c|}{$\begin{array}{l}\text { Cell volume } \\
\qquad\left(\mu \mathrm{m}^{3}\right)\end{array}$} & \multicolumn{2}{|c|}{$\begin{array}{c}\% \text { of total number } \\
\text { of HNF }\end{array}$} \\
\hline & Mean $\pm \mathrm{SD}$ & $\mathrm{n}$ & Mean \pm SD & $\mathrm{n}$ & Epi & Meta \\
\hline Spumella-like chrysomonads & $21 \pm 11$ & 102 & $16 \pm 6$ & 102 & 50.2 & 48.7 \\
\hline Bodonids & $36 \pm 17$ & 50 & $60 \pm 33$ & 50 & 10.7 & 11.3 \\
\hline Choanoflagellates & $53 \pm 19$ & 50 & $43 \pm 15$ & 50 & 11.0 & 9.5 \\
\hline Kathablepharis sp. & & & $97 \pm 33$ & 48 & 5.4 & 7.0 \\
\hline Cercomonas sp. & & & $80 \pm 27$ & 50 & 5.1 & 0 \\
\hline Goniomonas sp. & & & $146 \pm 44$ & 44 & 5.4 & 3.1 \\
\hline Streptomonas sp. & & & $996 \pm 439$ & 55 & 0.7 & 4.5 \\
\hline Unidentified & & & $78 \pm 63$ & 70 & 11.5 & 1.5 .9 \\
\hline
\end{tabular}




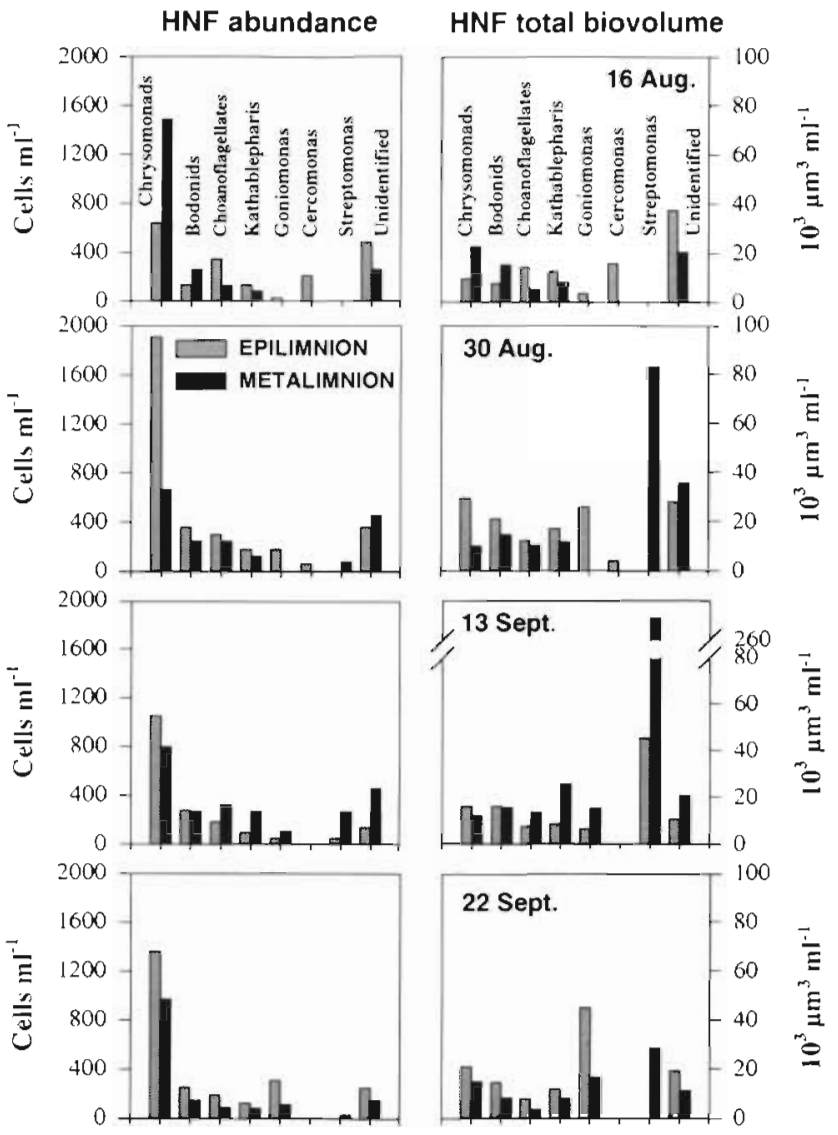

Fig. 4. Community structure of heterotrophic nanoflagellates (HNF) on 4 sampling dates, based on cell abundance and total biovolume

mostly zero uptake rates on FLB were observed among 44 to 50 individuals inspected per taxon which, moreover, were not present in all samples. Actually, Kathablepharis sp. was slightly more abundant in the metalimnion, but Goniomonas sp. in the epilimnion. Cercomonas sp., however, was found exclusively in the epilimnion whereas the largest $\left(996{\mu \mathrm{m}^{3}}^{3}\right.$ ), heartshaped Streptomonas sp. was remarkably more abundant in the metalimnion. The occurrence of these HNF taxa strongly influenced total HNF biomass (Fig. 4). For instance on 30 August and 13 September, Streptomonas $\mathrm{sp}$. in the metalimnion accounted for only 5 and $13 \%$ of total HNF numbers, but for 45 and $70 \%$ of total HNF biomass, respectively. Similarly, Goniomonas sp. accounted for $13 \%$ of total HNF numbers, but for $-35 \%$ of the total HNF biomass in the epilimnion on 22 September.

From microscopic observations, chrysomonads, bodonids and choanoflagellates appeared to be the major APP consumers in the reservoir. Flagellates contributed equally to the total protistan grazing on APP in both layers, on average $83 \%$, the remaining $17 \%$ was consumed by ciliates (Fig. 5). APP mean cell volumes were around $0.48 \mu^{3}$ in both layers (Simek et al. 1996), but their numbers dropped sharply from -3 to $4 \times 10^{5} \mathrm{ml}^{-1}$ at the beginning to $<2 \times 10^{3} \mathrm{ml}^{-1}$ by the end of the study (Fig. 5), likely due to protozoan grazing. In both layers, the amount of APP grazed per day was roughly equal (at the beginning) to or even severalfold higher (in the middle part of the study) than the APP standing stock. In parallel with the drop of A.PP numbers, there was a decrease in the cell-specific grazing rate of HNF on APP in both layers from -6 to 1 cell $\mathrm{HNF}^{-1} \mathrm{~h}^{-1}$ (Fig. 5). The cell-specific grazing rates of HNF on bacteria ranged from 9 to 32 and from 8 to 41 cells $\mathrm{HNF}^{-1} \mathrm{~h}^{-1}$ in the epi- and metalimnion, respectively (Fig. 6).

Using the data from both layers we plotted HNF clearance rates on bacteria against clearance rates on APP (Fig. 7). The clearance rates were calculated as grazing rates divided by prey abundance and all calculations of grazing rates were based on total numbers of HNF.

The position of all points above the 1:1 line indicated higher clearance rates of HNF on APP which were, in terms of cell volume, about 1 order of magnitude larger than the reservoir bacterioplankton (for details see
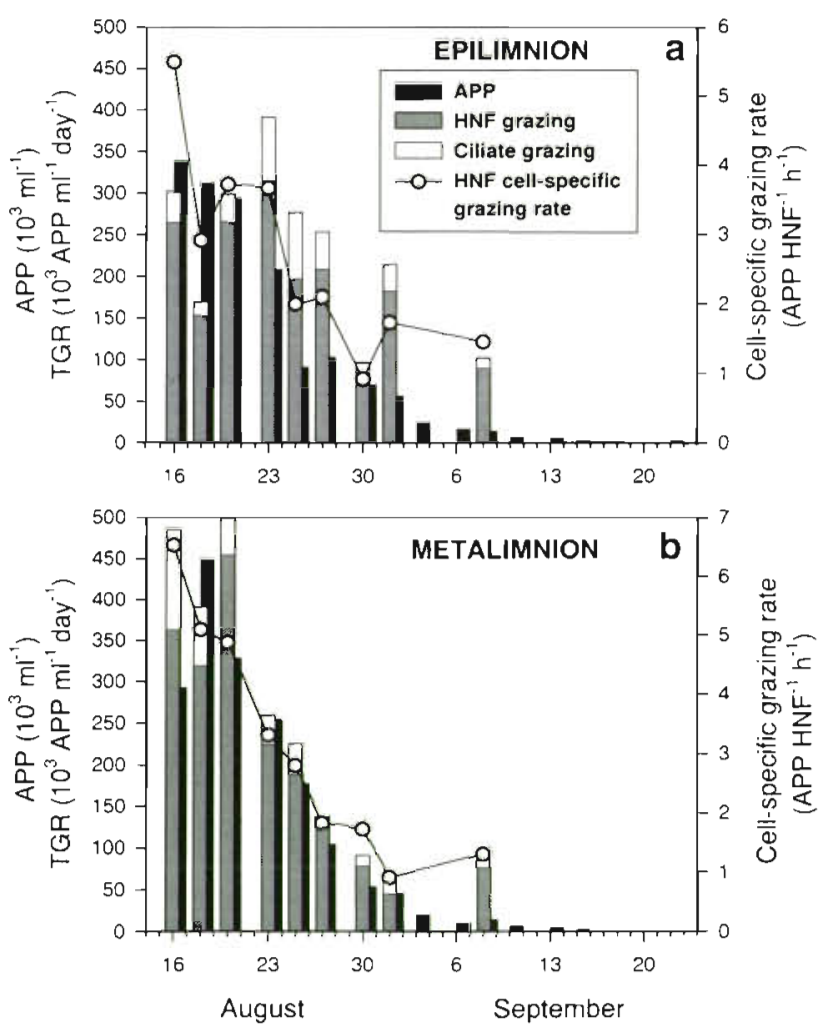

Fig. 5. Picocyanobacteria (APP) abundance, total protistan grazing rate (TGR) divided into flagellate and ciliate grazing on APP, and cell-specific grazing rate of heterotrophic nanoflagellates (HNF) on APP in the (a) epilimnion and (b) metalimnion, August-September 1993 

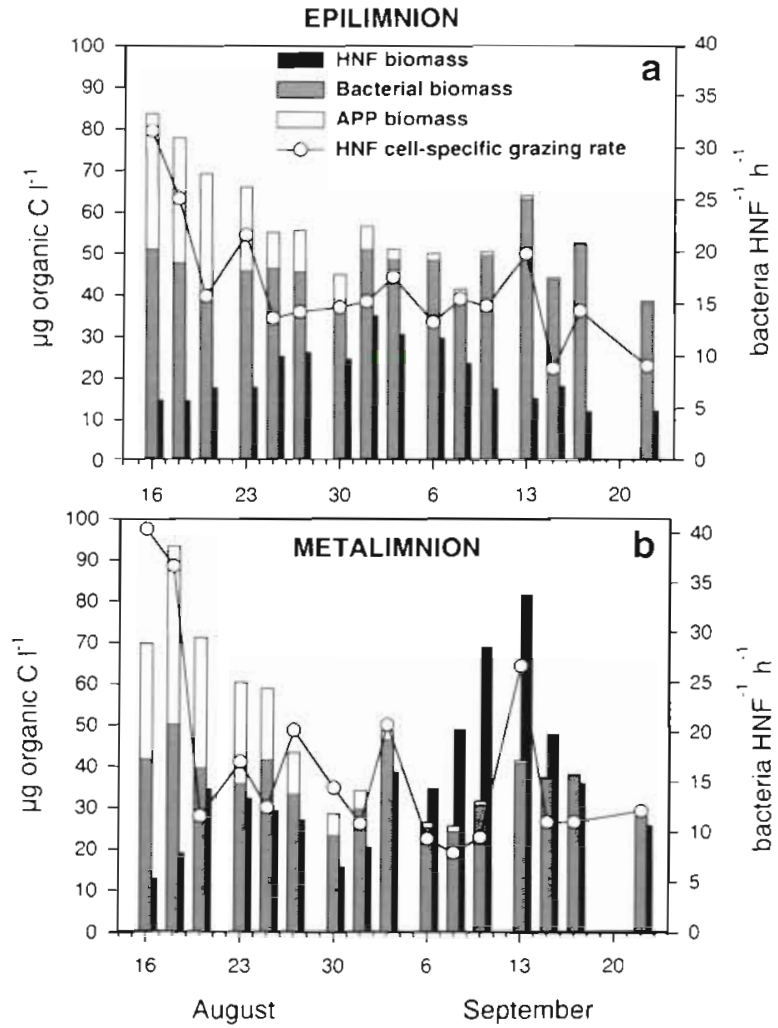

Fig. 6. Total picoplankton biomass (bacteria and APP) and total biomass and cell-specific grazing rate of helerotrophic nanoflagellates (HNF) on bacteria in the (a) epilimnion and

(b) metalimnion, August-September 1993

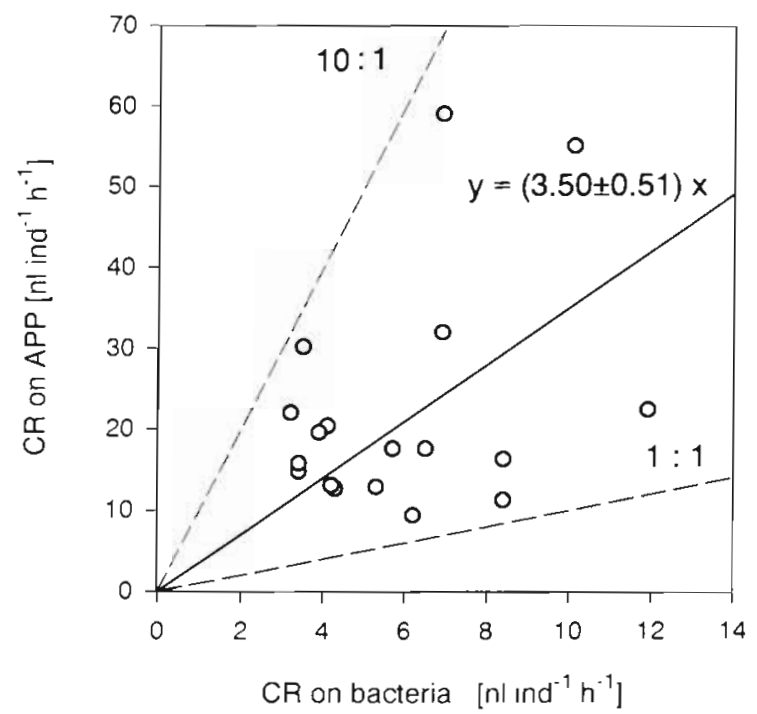

Fig. 7 Comparison of clearance rates (CR) of heterotrophic nanoflagellates calculated from ingestion rates of bacterioplankton and APP. All points from the epilimnion and metalimnion with simultaneous uptake measurements of both picoplankton food items pooled (16 August to 8 Seplember, $\mathrm{cf}$. Fig. 5). Dashed lines: 1:1 and 10:1 ratios; solid line: the best linear fit with the model $y=k \times x$
Simek et al. 1996). The calculated correlation forced through zero $(y=k \times x)$ indicated 3.5-fold higher clearance rates on APP than on bacteria.

The bulk of organic carbon in picoplankton 138 to 84 and 27 to $93 \mu \mathrm{g} \mathrm{l}^{-1}$ in the epilimnion and metalimnion, respectively) was dominated by bacteria (Fig. 6). APP in both layers constituted between 16 and $41 \%$ of the total picoplankton organic carbon during the first half of the study, but its proportion dropped to negligible levels during the second half of the study. As the numerical majority of HNF were picoplanktivorous, we compared the ratio of organic carbon in picoplankton biomass to HNF biomass (Fig. 6). In the epilimnion, this ratio (avg. $2.7 \pm 1.3$, range 1.6 to 5.7 ) was lowest $(<2)$ in the middle part of the study period when the species with low uptake rates on picoplankton, such as Kathablepharis sp. and Goniomonas sp., contributed significantly to the total HNF biomass (Fig. 4). In the metalimnion, the picoplankton:HNF biomass ratio (avg. $1.3 \pm 1.4$, range 0.5 to 5.3 ) was $>2$ only at the beginning of the study, decreasing then to values of $\sim 0.5$ (13 September) in parallel with an increasing biomass of Streptomonas sp. (cf. Figs. $4 \& 6$ ). For the last 2 sampling dates the ratio was around 1 .

\section{Relations of HNF to zooplankton groups and phytoplankton biomass}

Abundances and fluctuations of 6 zooplankton groups showed some notable differences between the epi- and metalimnion (Fig. 8) Daphnia (>95\% D. galeata), nauplii, and Cyclopidae were more abundant in the epilimnion, the former 2 groups especially during the second half of the study. At the beginning of the study, Eudiaptomus gracilis (generally $<20$ ind. $\mathrm{I}^{-1}$ ) and rotifer abundances (mostly 30 to 600 ind. $1^{1}$, dominated by Keratella cochlearis, Brachionus sp., and Polyarthra sp.) peaked in the epilimnion and metalimnion, respectively. The sum of Ceriodaphnia quadrangula and Diaphanosoma brachyurum showed similar abundances in both layers with increased numbers during the second half of the study. Chl a concentrations ranged from 7 to $112 \mu \mathrm{gl} \mathrm{l}^{-1}$ and from 10 to $60 \mathrm{\mu g} \mathrm{l}^{-1}$ in the epi- and metalimnion, respectively; for more details see Šimek et al. (1995).

Potential top-down and bottom-up control of HNF abundance and biomass was analyzed using non-parametric Spearman rank correlations (Statgraphics) of HNF parameters with zooplankton and chl a concentrations. As the epi- and metalimnion significantly differed in some parameters, we analyzed data from both layers separately and pooled data as well (Table 4). Here, we list only those correlations with plankton groups that were significant in at least 1 layer or in the 
pooled data, i.e. all respective correlations with ciliates, nauplii, rotifers and Eudiaptomus gracilis were insignificant. Among zooplankton groups tested, cladocerans (especially the Ceriodaphnia quadrangula and Diaphanosoma brachyurum group) showed the strongest negative influence on numbers and biomass of HNF, at least in the epilimnion. This influence was even stronger when a group of the total herbivorous crustacean zooplankton was used (Daphnia galeata, $C$. quadrangula, D. brachyurum, E. gracilis and nauplii together), i.e. all those crustaceans potentially feeding on particles covering the HNF size range. Changes in HNF abundance and biomass were significantly negatively correlated with changes in the abundance of the total herbivorous crustacean zooplankton in the epilimnion. The corresponding correlations for the metalimnion were insignificant, likely due to mostly lower numbers of these zooplankters within the layer (Fig. 8).

The mean cell volume of HNF decreased with the abundance of the group of Ceriodaphnia quadrangula and Diaphanosoma brachyurum, and Cyclopidae in the metalimnion, and, moreover, with the numbers of Daphnia galeata in the pooled data set. These relationships indicated a top-down control of these zooplankton groups on large HNF dominated by Streptomonas sp. in the metalimnion. On the other hand, positive and highly significant correlations were found between chl a concentrations and the biomass and the mean cell volume of HNF in the metalimnion, indicating a tight linkage between the concomitant development of high numbers of Streptomonas sp. (Fig. 4) and a high phytoplankton biomass dominated by chlorophytes (especially Staurastrum pingue; Simek et al. 1995)
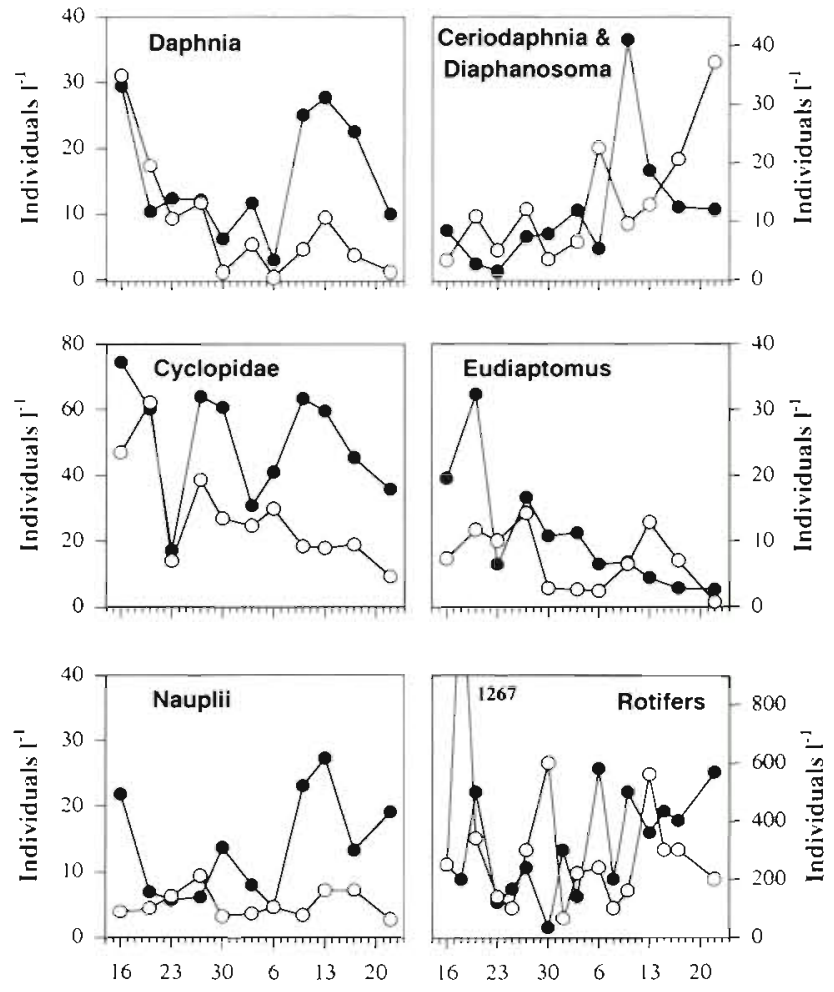

August September

August September

EPILIMNION - - METALIMNION

Fig. 8. Changes in abundance of zooplankton species or groups in the epilimnion and metalimnion, August-September 1993: Daphnia (>95\% D. galeata), sum of Ceriodaphnia quadrangula and Diaphanosoma brachyurum, Cyclopidae Eudiaptomus gracilis, nauplii, and rotifers

Table 4. Spearman rank correlations of HNF parameters with selected zooplankton parameters and phytoplankton biomass (chl a), August-September 1993. For chl $a, n=16$ for the epi- and metalimnion, $\mathrm{n}=32$ for the pooled sample. For relations with zooplankton groups, $n=11$ for the epi- and metalimnion, $n=22$ for the pooled sample. Epi: epilimnion; Meta: metalimnion; All pooled data from both layers; Cer + Dia: Ceriodaphnia quadrangula and Diaphanosoma brachyurum together; Total cladocerans Daphnia galeata, C. quadrangula and D. brachyurum together; Total herbivorous crustaceans: D. galeata, C. quadrangula, D brachyurum, Eudiptomus gracilis and nauplii together; ${ }^{p} p<0.05, \cdots p<0.01, \cdots p<0.001$

\begin{tabular}{|c|c|c|c|c|c|c|}
\hline & $\begin{array}{l}\text { Daphnia } \\
\text { galeata }\end{array}$ & Cer + Dia & $\begin{array}{c}\text { Total } \\
\text { cladocerans }\end{array}$ & $\begin{array}{c}\text { Total herbivorous } \\
\text { crustaceans }\end{array}$ & Cyclopidae & Chl a \\
\hline \multicolumn{7}{|c|}{ Number of HNF } \\
\hline All & 0.054 & $-0.541^{*}$ & $-0.527^{\bullet}$ & -0.262 & 0.162 & -0.282 \\
\hline Epi & -0.501 & $-0.706^{\circ}$ & $-0.623^{\circ}$ & $-0.724^{\circ}$ & -0.200 & -0.259 \\
\hline Meta & 0.482 & -0.337 & -0.237 & 0.054 & 0.373 & -0.365 \\
\hline \multicolumn{7}{|c|}{ Biomass of HNF } \\
\hline All & $-0.537^{\circ}$ & 0.131 & -0.290 & $-0.525^{\circ}$ & $-0.468^{\circ}$ & 0.148 \\
\hline Epi & -0.509 & -0.509 & -0.518 & $-0.627^{\circ}$ & -0.164 & 0.037 \\
\hline Meta & -0.091 & 0.333 & -0.342 & -0.255 & -0.309 & $0.748 \cdots$ \\
\hline \multicolumn{7}{|c|}{ Mean cell volume of HNF } \\
\hline All & $-0.572^{\cdots}$ & $-0.479^{\circ}$ & 0.057 & -0.356 & $-0.519^{*}$ & 0.143 \\
\hline Epi & 0.109 & 0.355 & 0.300 & 0.136 & 0.181 & 0.377 \\
\hline Meta & -0.364 & $-0.679^{\circ}$ & -0.027 & -0.155 & $-0.673^{\cdots}$ & $0.825 \cdots$ \\
\hline
\end{tabular}




\section{DISCUSSION}

\section{Comparison of bacterial production and its consumption}

One might have expected significant correlations between parameters of bacterial production, BP-thy and BP-num (Table 2), however, all relations between these 2 parameters were insignificant, likely due to the different treatment and the length of sample incubation. One possible source for the imbalance between parameters of bacterial production and bacterivory could be oscillations of these parameters over a diurnal cycle (Wikner et al. 1990, Christoffersen 1994), which might especially affect parameters derived from the short-term incubations, such as BP-thy and TPGR. A more detailed discussion of potential biases of the latter parameters has already been reported (Šmek et al. 1995). In contrast, $24 \mathrm{~h}$ incubation of samples under constant conditions in the dark (BP-num and FLBdisap) may reduce the influence of a diurnal cycle. Moreover, prefiltration through $1 \mu \mathrm{m}$ pore-size filters (BP-num) might stimulate bacteria, giving faster and more effective growth (Smits \& Riemann 1988), but it might also decrease bacterial growth rate as a consequence of a lower dissolved organic carbon availability caused by the absence of algae.

As the major part of bacterial production was consumed by protists, one could expect a very tight relátionship between these parameters. Some typical seasonal studies with a sampling frequency of 1 wk or longer (e.g. Sanders et al. 1989, Chrzanowski \& Simek 1993), or the comparison of different ecosystems (Sanders et al. 1992), documented this tight predator-prey linkage by highly significant correlations between protistan bacterivory and bacterioplankton growth rate. Surprisingly, we did not find such highly significant correlations (Table 2) in this study with a sampling frequency of 3 times a week. This might be explained by very frequent oscillations of both parameters (Fig. 3), or a time shift between them in the order of several hours which was not detectable with our experimental design.

Very similar mean values of TPGR and FLB-disap and significant correlations (Tables $1 \& 2$ ) indicated that protozoa were the major source of bacterial mortality in the different incubations. Some rotifers, which may have been present along with protozoa in the samples for estimations of FLB disappearance rate (water screened through a $100 \mu \mathrm{m}$ mesh), could have a small influence on the total rate of bacterivory. We did not find, however, any significant correlations between numbers and species composition of rotifers on the one hand, and bacterial parameters and HNF (as the major bacterivores) on the other.
During population peaks, cladocerans become the main consumers of bacterial production in lakes (e.g. Šimek et al. 1990, Vaqué \& Pace 1992, Jürgens 1994). However, they seemed to be insignificant bacterivores during the summer season in the reservoir for several reasons: (1) we estimated that $-90 \%$ of bacterial production was consumed by protists (Fig. 3), (2) cladocerans were generally not abundant enough to exert a significant grazing impact on bacterioplankton (Fig. 8), and (3) no significant correlation was found between cladoceran abundance and parameters of bacterial numbers, biomass and production (data not shown).

\section{Community composition of HNF and their role as picoplankton consumers}

We observed almost no uptake of fluorescent tracers by pigmented flagellates, and HNF were the main bacterivores in the reservoir, as is common in many freshwater lakes (e.g. Berninger et al. 1991, Sanders et al. 1992, Chrzanowski \& Śimek 1993). However, our data showed a different role of picoplankton in the diet of several taxonomic groups of HNF.

The smallest HNF, chrysomonads, bodonids, and choanoflagellates, were the most abundant (especially 2.5 to $6 \mu \mathrm{m}$ large Spumella-like chrysomonads; Fig. 4, Table 3) as in the case of other temperate lakes (Sanders et al. 1989, Bennett et al. 1990, Springmann 1993 , Mathes \& Arndt 1994). They also showed the highest taxon-specific uptake rates on bacteria (Table 3), but as we did not measure the corresponding values on APP, only a mean uptake rate of APP per HNF is presented ( 2.9 cells $\mathrm{HNF}^{-1} \mathrm{~h}^{-1}$ ). Taxon-specific cell volumes of HNF and cell volumes of their ingested picoplankton prey were transformed to carbon units

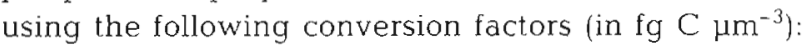
HNF, 220 (Børsheim \& Bratbak 1987); bacteria, 287 (according to Norland 1993, corresponding to the mean cell volume of the reservoir bacteria of $0.047 \mathrm{\mu m}^{3}$ ); picocyanobacteria, 200 (Weisse 1993). Assuming a gross growth efficiency of $40 \%$ for bacterivorous HNF (Fenchel 1982) and using our estimates of ingestion, the doubling times of chrysomonads, bodonids, and choanoflagellates would be 18,38 , and $24 \mathrm{~h}$, respectively. Edelmann (1993) reported a very similar average doubling time of $\mathrm{HNF}<5 \mu \mathrm{m}$. $(37 \mathrm{~h}$, $>50 \%$ chrysomonads) for the period April-October 1993 in the Rímov reservoir, estimated from changes in HNF abundance in the absence of their predators. Also, Jürgens (1992) found that small chrysomonads are well adapted to exploit and grow on in situ bacterial concentrations. Since monodispersed FLB and FLC were used, the grazing data for bodonids might be partly underestimated, as these forms are usually asso- 
ciated with surfaces and specialized in feeding on attached bacteria (Caron 1987). Choanoflagellates were mostly observed as sessile forms on cells of Staurastrum pingue and Fragillaria crotonensis, constituting the major portion of phytoplankton biomass in the reservoir (Simek et al. 1995).

Our splitting of HNF into taxonomic groups supplemented by their uptake rates on picoplankton showed that only a portion, i.e. chrysomonads, bodonids, and choanoflagellates, are true bacterivores. For larger HNF (see Fig. 4) we observed negligible uptake rates on picoplankton which would not allow them to meet their carbon requirements. Cercomonas spp. were mostly considered as bacterivorous (Patterson \& Zölffel 1991) which was not clearly confirmed in our study. Goniomonas sp., tentatively identified as G. truncata, was likely able to grow without particulate food (Sanders 1991), which supported both our field data (this study) and observations from laboratory stock cultures (Simek unpubl. data), in which almost no uptake of both FLB and FLC was recorded. Kathablepharids were rarely found ingesting picoplankton, but we frequently observed them with ingested autofluorescing cells of blue-greens or algae in a size range from 1.5 to $4 \mu \mathrm{m}$. However, FLB could be substantially different from natural bacterioplankton regarding cell surface properties, motility, etc. Thus, we could not completely exclude the possibility of selection for or against such tracers by respective taxa of HNF (Landry et al. 1991, Sherr \& Sherr 1993)

There are no literature data about a planktonic mass occurrence of Streptomonas sp. This heart-shaped flagellate $(12$ to $20 \mu \mathrm{m})$ with a rigid cell and 2 equal flagella inserting into an anterior depression (Patterson \& Zölffel 1991) only rarely ingested picoplankton or algae in the size range of 1 to $4 \mu \mathrm{m}$, thus its prevailing feeding mode remains unclear. Its abundance ( $>300$ ind $\mathrm{ml}^{-1}$ ) and biomass ( 4 times higher than that of the total picoplankton!) peaked in the metalimnion on 13 September, concomitantly with a heavy bloom of Staurastrum pingue and large blocks of Fragillaria crotonensis (cf. Simek et al. 1995). It indicated that the community contains specific food niches, where the flagellates profited from feeding within the surroundings or at the surfaces of the large algae. The specific conditions of the algal bloom also favored the development of populations of detritophagous ciliate species, such as Coleps sp., Cyrtolophosis mucicola and Cinetochilum margaritaceum (Šimek et al. 1995). Thus, detritivory could also be of some importance for Streptomonas sp. An important part of flagellate - although not of HNF - biomass was composed by a mixotrophic dinoflagellate, Ceratium hirundinella. We did not observe phagotrophy so we included this species into the phytoplankton biovolume (Simek et al. 1995).
The contributions of different groups to total numbers and biomass of HNF (Fig. 4) in the Rímov reservoir was very similar to those reported for temperate lakes, such as Lake Constance (Springmann 1993), Mondsee (Salbrechter \& Arndt 1994), Piburger See (Pernthaler et al. 1996b), and lakes in Northern Germany (Mathes \& Arndt 1994). Small picoplanktivorous HNF numerically dominated throughout the study (Fig. 4). However, in terms of biomass, especially in the metalimnion, usually $H N F \geq 10 \mu \mathrm{m}$ became more important (see also Mathes \& Arndt 1994) with phytophagous forms dominating, and also very likely with an important role for osmotrophs (Goniomonas sp.) or detritivores (Streptomonas sp.).

While the biomass range in picoplankton was very similar in the epi-and metalimnion (Fig. 6), there were significant differences in the picoplankton:HNF carbon ratio. Assuming a $40 \%$ gross growth efficiency of HNF, total picoplankton in the epilimnion would be quantitatively a carbon source sufficient for $\mathrm{HNF}$ growth, except for a short period in the middle of the study. In the metalimnion, the picoplankton:HNF carbon ratio indicated that picoplankton was not even quantitatively sufficient to support the HNF growth, except for a short period at the beginning of the study. Moreover, considering the dominance of very small bacterioplankton cells (Fig. 2), this ratio does not reflect the availability of different sizes of picoplankton as food for HNF (cf. Simek \& Chrzanowski 1992, Shimeta 1993).

Generally, our APP abundances fit well in the range of values reported by Weisse (1993 and references therein) for lakes and reservoirs of similar trophy. Numerous plankton organisms of different taxonomic position have been identified as APP feeders (see review of Stockner \& Antia 1986), but HNF and ciliates are considered as primary consumers of APP both in marine and fresh waters (e.g. Nagata 1988, Kuosa 1991, Weisse 1993, Simek et al. 1995). We paid specific attention to the role of protozoa in controlling APP abundance, the sharp decrease of which could be explained by protozoan grazing. We did not measure APP growth rate, but assuming 1 doubling daily (mean value reported for freshwaters; Weisse 1993), our data indicate that APP would have been subjected to significant grazing pressure by protozoa.

This study and our recent reports (Simek et al. 1995, 1996) are among the first presenting species- or taxonspecific grazing rates of dominant freshwater planktonic protists on APP (see also Sherr et al. 1991). Among the reservoir HNF, accounting for $83 \%$ of the total protistan grazing on APP, small Spumella-like chrysomonads, bodonids and choanoflagellates contributed 40 to 60,5 to 15 , and 5 to $15 \%$, respectively, while grazing by other groups of HNF was negligible. 
However, as APP disappeared by the middle of the experiment (Fig. 5) we could not collect a sufficiently large set of data as presented for taxon-specific grazing rates on bacteria (cf. Table 3). Among ciliates, small oligotrichs, dominated by Halteria grandinella and Strobilidium hexakinetum, were the major APP consumers (Simek et al. 1995). Also in the oligomesotrophic lake Piburger See, choanoflagellates and chrysomonads among HNF, and an oligotrichous ciliate, Pelagohalteria viridis, were found to be the major picoplanktivores (Pernthaler et al. 1996b, Simek et al. 1996).

APP have been frequently observed in food vacuoles of protozoa in lakes (e.g. Nagata 1988, Sherr et al. 1991, Christoffersen 1994, Simek et al. 1995), but their digestibility, nutritional value, and uptake selectivity are largely unknown. In laboratory experiments, Caron et al. (1991) investigated ingestion of Paraphysomonas sp. and 2 species of ciliates on 3 strains of Synechococcus sp. and 2 strains of heterotrophic bacteria. Only 1 ciliate selected against Synechococcus when offered a mixed diet of cyanobacteria and bacteria. When cyanobacteria were the sole food source, the growth efficiencies of the protozoa were substantially lower than in the presence of bacteria, likely due to an incomplete digestion of Synechococcus. In contrast, Müller (1966) reported that Paraphysomonas sp. selected for 2 out of 3 Synechococcus species over bacteria in laboratory experiments. From field experiments on picoplankton consumption by protozoa in coastal waters, Caron et al. (1991) concluded that protists usually do not select for or against natural Synechococcus cells. These inconsistent conclusions suggest that species-specific properties of predator and prey might strongly influence digestibility and the selection among Synechococcus strains.

In food vacuoles of ciliates we observed APP in various degrees of digestion. Moreover, a tight predator-prey linkage supported significant correlations between the abundance of ciliates, Halteria grandinella (Simek et al. 1995, this study) and Pelagohalteria viridis (lake Piburger See; Simek et al. 1996) and abundance of APP Also the proportion of small picoplanktivorous forms in the total HNF numbers and biomass was higher during the first half of the study, when APP accounted for a more significant part of the total picoplankton biomass (cf. Figs. $4 \& 6$ ). From the ingestion rates of chrysomonads, bodonids, and choanoflagellates we calculated that picocyanobacteria constituted 49,30 , and $39 \%$ of the total picoplanktonic carbon ingested, respectively. Although we had to use only the mean grazing rate for all HNF on APP, instead of taxon-specific grazing rates as used for grazing on bacteria, the above data strongly support the idea that APP are important in the diet of HNF.
The data from 2 very different systems, the eutrophic Rímov reservoir and the oligo-mesotrophic lake Piburger See, revealed much higher clearance rates of protists on APP compared to bacteria, for HNF they were on average -3 times (Pernthaler et al. 1996b, this study), and for ciliates 2 to 4 times higher (Simek et al. 1995, 1996). It has been reported that both HNF and ciliates appear to be size-selective consumers of various picoplankton prey in freshwaters (Šimek \& Chrzanowski 1992, Jürgens \& Güde 1994, Simek et al. $1994,1995)$. The protists not only cropped the major proportion of bacterial production in the reservoir (Fig. 3), they also seemed to be responsible for keeping a very stable bacterial size structure dominated by cells within a length range of 0.4 to $0.8 \mu \mathrm{m}$. On the basis of a model, Shimeta (1993) suggested that the size around $0.4 \mu \mathrm{m}$ acts as the refuge at which bacterial particles have the lowest encounter rate resulting in the minimal probability of being grazed by suspension feeders. This also fits well the concept of grazing-resistant bacteria of Jürgens \& Güde (1994). With respect to the significant positive correlation we found between TPGR and bacterial abundance, the very stable size structure could result from protistan grazing upon larger and fast growing bacterial cells (see also Pernthaler et al. 1996a). Thus, although the majority of bacterial cells were extremely small and other size classes had little effect on the total biomass (Fig. 2), the reservoir bacterioplankton grew with an average doubling time of $2 \mathrm{~d}$. As doubling times of bacterivorous HNF (Edelmann 1993) and ciliates (Macek et al. 1996. Simek et al, 1996) also ranged between 1 and $3 d$; the data indicate a very tight predator-prey linkage within the reservoir microbial food webs.

\section{Bottom-up and top-down control of HNF}

Gasol et al. (1995) showed, based on an extensive data set from 16 Quebec lakes, that HNF resource factors (total phosphorus, chl, bacterial numbers) best explained the abundances of HNF among lakes differing in trophy. Within lakes, however, HNF abundance was not a direct function of resource concentration. The analysis of seasonal patterns among lakes further showed that the bottom-up variables were more important in spring and top-down variables in summer. Our study was timed from mid- to late summer, when heavy algal blooms, typically dominated by large inedible phytoplankters, occur (Komárková 1994), resulting, together with strong grazing pressure exerted by fish, in moderate to low abundances of metazooplankton in the reservoir (Straškrabová et al. 1993, Brandl 1994). We did not find a tight linkage of HNF abundance to the resource parameters by statisti- 
cal comparison, as there were no significant relationships between HNF abundance and concentrations of bacteria and chl. On the other hand, observations of protistan food vacuole contents clearly showed the importance of picoplankton in the diet of HNF. In comparison to HNF numbers, HNF biomass and a mean cell volume were tightly correlated with chl in the metalimnion, seemingly due to the dominance of large cells of Streptomonas sp. in HNF biomass (Fig. 4).

Our data exemplified that the analysis of resource limitation of HNF populations and a determination and refinement of the main carbon fluxes within microbial food webs requires taxonomic insight at least at the functional level of HNF groups. For instance, bacterivory was tightly coupled with community structure and supported around $70 \%$ of HNF in terms of their numbers but probably $<30 \%$ of HNF in terms of biomass. Thus algivory, detritivory, and osmotrophy were likely the prevailing feeding modes among larger HNF in the Rímov reservoir (cf. Sanders 1991, Mathes \& Arndt 1994, Sherr \& Sherr 1994).

While we directly quantified the carbon flux from picoplankton to protozoa, the correlation analysis only gave indirect evidence for a top-down control of HNF by metazooplankton. Due to the lower summer abundances of metazooplankton in the reservoir, the negative correlations we found were not as strong as reported in other studies where seasonality and heterogeneity between lakes were involved (e.g. Pace et al. 1990, Simek et al. 1990, Vaqué \& Pace 1992, Jürgens 1994, Gasol et al. 1995). The largest proportion of variability in the HNF number and biomass data in the epilimnion was explained by pooled abundances of all potential crustacean consumers of HNF (Table 4). In the metalimnion, different groups of zooplankton, the sum of Ceriodaphnia quadrangula and Diaphanosoma brachyurum, and Cyclopidae negatively correlated with the mean cell volume of HNF. Cyclopoid copepods are efficient predators on ciliates (Kornyenko 1976); this was supported by an inverse relationship between numbers of cyclops and the abundance and biomass of ciliates dominated by small forms of $\sim 20 \mu \mathrm{m}$ (Šimek et al. 1995). As Streptomonas sp. also falls into the same size range, the HNF mean cell volume in the metalimnion could have been influenced especially through copepod grazing on this large flagellate (Table 4).

Planktonic rotifers, considered as important HNF consumers (Dolan \& Gallegos 1991, Arndt 1993, Sanders \& Wickham 1993), numerically dominated the reservoir metazooplankton (Fig. 8). Surprisingly, using a very similar sampling frequency as reported in the field studies of Dolan \& Gallegos (1991) and Pernthaler et al. (1996b), our data did not confirm the tight preda- tor-prey linkage as neither total abundance of rotifers nor abundances of presumably nano-or microphagous species of rotifers, i.e. Keratella cochlearis, Polyarthra sp., and Brachionus sp. (Sanders \& Wickham 1993), were correlated with HNF parameters (data not shown). Basically the same holds also for ciliates, which might partly result from the prevailing sizes of reservoir HNF and ciliates. Although oligotrichs are very efficient consumers of small HNF under laboratory conditions (Jürgens et a1, 1997), and HNF are generally considered as potentially important food source for ciliates (e.g. Weisse 1991), our data did not support the tight food linkage between these protists.

\section{Conclusions}

A complex food web structure developed during the period of the summer phytoplankton peak in the eutrophic Rímov reservoir (Figs. 4, 5 \& 8). Bottom-up (picoplankton abundance, phytoplankton composition, and chl) and top-down factors (especially cladocerans and the sum of all herbivorous crustaceans; Table 4) varied in their impact on abundance, biomass and taxonomic structure of the reservoir HNF. To determine the main carbon fluxes within microbial food webs, the dominant protists must be identified at least at a functional level. Among protists, small HNF (chrysomonads, bodonids and choanoflagellates) consumed the major part (ca 80 to $85 \%$ ) of both bacterial and APP production in the reservoir, while the rest was grazed by ciliates (Figs. $3 \& 5$ in this study, and Simek et al. 1995). In terms of available organic carbon and uptake selectivity, APP represents a food source of high importance, but further studies are necessary to assess their digestibility and nutritional adequacy for planktonic protozoa on a species-specific basis.

Both the sharp decrease in APP abundance and the typical size structure of bacterioplankton cells dominated by short rods were apparently caused by heavy protozoan grazing. Besides picoplanktivory, recognized as the most important feeding mode of numerically dominating small HNF, other feeding modes such as algivory, detritivory, and osmotrophy were likely of high importance for larger HNF dominating in terms of biomass (see also Sanders 1991, Mathes \& Arndt 1994), especially in the metalimnion of the reservoir.

Acknowledgements. We thank John Dolan, Věra Straškrabová, Klaus Jürgens, and Helga Müller for comments on earlier versions of the manuscript and Angela Schwarzenbacher for help with processing of the data from image analysis. This study was supported by the Austrian Ministry of Research awarded to R.P. (OST-WEST Project, GZ 45.281/3-IV/6a/93), and by CAS GA research grant 617102 and GA CR research grant 206/96/0012 awarded to K.S. 


\section{LITERATURE CITED}

Arndt $H$ (1993) Rotifers as predators on components of the microbial web (bacteria, heterotrophic flagellates, ciliates) - a review. Hydrobiologia 255/256:231-246

Bennett SJ, Sanders RW, Porter KG (1990) Heterotrophic, autotrophic, and mixotrophic nanoflagellates: seasonal abundance and bacterivory in a eutrophic lake. Limnol Oceanogr 35:1821-1832

Berninger UG, Finlay BJ, Kuuppo-Leinikki P (1991) Protozoan control of bacterial abundances in freshwaters. Limnol Oceanogi 36:139-147

Børsheim KY, Bratbak G (1987) Cell volume to carbon conversion factors for a bacterivorous Monas sp. enriched from seawater. Mar Ecol Prog Ser 36:171-175

Brandl Z (1994) The seasonal dynamics of zooplankton biomass in two Czech reservoirs: a long-term study. Arch Hydrobiol Beih Ergebn Limnol 40:127-135

Caron DA (1987) Grazing of attached bacteria by heterotrophic microflagellates. Microb Ecol 13:203-218

Caron DA, Lim EL, Miceli G, Waterbury JB, Valois FW (1991) Grazing and utilization of chroococcoid cyanobacteria and heterotrophic bacteria by protozoa in laboratory cultures and a coastal plankton community. Mar Ecol Prog Ser 76: $205-217$

Christoffersen K (1994) Variations of feeding activities of heterotrophic nanoflagellates on picoplankton. Mar Microb Food Webs 8:111-123

Chrzanowski TH, Simek K (1993) Bacterial growth and losses due to bacterivory in a mesotrophic lake. J Plankton Res 15:771-785

Dolan JR, Gallegos CL (1991) Trophic coupling of rotifers, microflagellates, and bacteria during fall months in Rhode River Estuary. Mar Ecol Prog Ser 77:147-156

Edelmann Z (1993) Seasonal dynamics of bacterioplankton in the Rímov reservoir - interactions with heterotrophic nanoflagellates. Diploma thesis, Charles University, Prague, p 77 (in Czech)

Fenchel T (1982) Ecology of heterotrophic nanoflagellates. IV. Quantitative occurrence and importance as bacterial consumers. Mar Ecol Prog Ser 9:35-42

Fenchel $T$ (1987) Ecology of protozoa: the biology of freeliving phagotrophic protists. Science Technical Publishers Madison, WI

Finlay BJ, Clarke KJ, Cowling AJ, Hindle RM, Rogerson A Berninger UG (1988) On the abundance and distribution of protozoa and their food in a productive freshwater pond. Eur J Protistol 23:205-217

Gasol JM. Simons AM. Kalff J (1995) Patterns in the topdown versus bottom-up regulation of heterotrophic nanoflagellates in temperate lakes. J Plankton Res 17 $1879-1903$

Jürgens K (1992) Is there plenty of food for bacterivorous flagellates in eutrophic waters? Arch Hydrobiol Beih Ergebn Limnol 37:195-205

Jürgens K (1994) Impact of Daphnia on planktonic microbial food webs. A review. Mar Microb Food Webs 8:295-324

Jürgens K, Güde H (1994) The potential importance of grazing-resistant bacteria in planktonic systems. Mar Ecol Prog Ser 112:169-188

Jürgens K. Wickham SA, Rothhaupt KO, Santer B (1997) Feeding rates of macro- and microzooplankton on heterotrophic nanoflagellates. Limnol Oceanogr 42 (in press)

Komárkovã J (1994) Phytoplankton cycles in the Rimov Reservoir (South Bohemia). Arch Hydrobiol Beih Ergebn Limnol $40: 81-84$
Kornyenko GS (1976) Contribution of infusoria to the nutrition of Acanthocyclops vernalis and Cyclops vicinus. Hydrobiol J 12:62-65

Kuosa H (1991) Picoplanktonic algae in the northern Baltic Sea: seasonal dynamics and flagellate grazing. Mar Ecol Prog Ser 73:269-276

Landry MR, Lehner-Fournier JM, Sundström JA, Fagerness VL, Selph K (1991) Discrimination between living and heat-killed prey by a marine zooflagellate, Paraphysomonas vestita (Stokes). J Exp Mar Biol Ecol 146:139-151

Macek M, Simek K, Pernthaler J, Vyhnálek V. Psenner R (1996) Growth rate of dominant planktonic ciliates in two freshwater bodies of different trophic degree. J Plankton Res 18:463-481

Marchant HJ (1972) Processing small delicate biological specimens for scanning electron-microscopy. J Microsc 97 $369-371$

Mathes J, Arndt H (1994) Biomass and composition of protozooplankton in relation to lake trophy in north German lakes. Mar Microb Food Webs 8:357-375

McCauley $\mathrm{E}$ (1984) The estimation of the abundance and biomass of zooplankton in samples. In: Downing JA, Rigler FH (eds) A manual on methods for the assessment of secondary productivity in fresh waters. IBP Handbook No. 17, Blackwell Scientific Publications, Oxford, p 228-266

Müller H (1996) Selective feeding of a freshwater chrysomonad, Paraphysomonas sp., on chroococcoid cyanobacteria and nanoflagellates. Arch Hydrobiol Beih Ergebn Limnol 48:63-71

Nagata T (1988) The microflagellate-picoplankton food linkage in the water column of Lake Biwa. Limnol Oceanogr $33: 504-507$

Norland $S$ (1993) The relationship between biomass and vo]ume of bacteria. In: Kemp PF, Sherr BF, Sherr EB, Cole JJ (eds) Handbook of methods in aquatic microbial ecology. Lewis Publ, Boca Raton, p 303-308

Pace ML, McManus GB, Findlay SEG (1990) Planktonic community structure determines the fate of bacterial production in a temperate lake. Limnol Oceanogr 35: $795-808$

Patterson DJ, Larsen J (1991) The biology of free-living heterotrophic flagellates. Clarendon Press, Oxford

Patterson DJ, Zölffel M (1991) Heterotrophic flagellates of uncertain taxonomic position. In: Patterson DJ, Larsen J (eds) The biology of free-living heterotrophic flagellates. Clarendon Press, Oxford, p $427-475$

Pernthaler J, Sattler B, Simek K, Schwarzenbacher A, Psenner $R$ (1996a) Top-down effects on the size-biomass distribution of a freshwater bacterioplankton community. Aquat Microb Ecol 10:255-263

Pernthaler J, Simek $K$, Sattler $B$, Schwarzenbacher $A$, Bobková J, Psenner R (1996b) Short-term changes of protozoan control on autotrophic picoplankton in an oligomesotrophic lake. J Plankton Res 38:443-462

Psenner R (1993) Determination of size and morphology of aquatic bacteria by automated image analysis. In: Kemp PF, Sherr BF, Sherr EB, Cole JJ (eds) Handbook of methods in aquatic microbial ecology. Lewis Publ, Boca Raton, p $339-345$

Riemann B, Sondergaard M (1986) Carbon dynamics in eutrophic, temperate lakes. Elsevier, Amsterdam

Salat J, Marrasé C (1994) Exponential and linear estimations of grazing on bacteria: effects of changes in the proportion of marked cells. Mar Ecol Prog Ser 104:205-209

Salbrechter M. Arndt H (1994) The annual cycle of protozooplankton in the alpine, mesotrophic Lake Mondsee (Austria). Mar Microb Food Webs 8:217-234 
Sanders RW (1991) Trophic strategies among heterotrophic flagellates. In: Patterson DJ, Larsen J (eds) The biology of free-living heterotrophic flagellates. Clarendon Press, Oxford, p 21-38

Sanders RW, Caron DA, Berninger G (1992) Relationship between bacteria and heterotrophic nanoplankton in manne and fresh waters: an inter-ecosystem comparison. Mar Ecol Prog Ser 86:1-14

Sanders RW, Porter KG, Bennett SJ, DeBiase AE (1989) Seasonal patterns of bacterivory by flagellates, ciliates, rotifers, and cladocerans in a freshwater planktonic community. Limnol Oceanogr 34:673-687

Sanders RW, Wickham SA (1993) Planktonic protozoa and metazoa: predation, food quality and population control. Mar Microb Food Webs 7:197-223

Sherr EB, Sherr BF (1988) Role of microbes in pelagic food webs: a revised concept. Limnol Oceanogr 33:1225-1227

Sherr EB, Sherr BF (1993) Protistan grazing rates via uptake of fluorescently labeled prey. In: Kemp PF, Sherr BF, Sherr $E B$, Cole JJ (eds) Handbook of methods in aquatic microbial ecology. Lewis Publ, Boca Raton, p 695-701

Sherr EB, Sherr BF (1994) Bacterivory and herbivory: key roles of phagotrophic protists in pelagic food webs. Microb Ecol 28:223-235

Sherr EB, Sherr BF, Berman T, Hadas O (1991) High abundance of picoplankton-ingesting ciliates during late fall in Lake Kinneret, Israel. J Plankton Res 13:789-799

Shimeta J (1993) Diffusional encounter of submicrometer particles and small cells by suspension feeders. Limnol Oceanogr 38:456-465

Simek K, Bobková J, Macek M, Nedoma J, Psenner R (1995) Ciliate grazing on picoplankton in a eutrophic reservoir during the summer phytoplankton maximum: a study at the species and community level. Limnol Oceanogr 40: $1077-1090$

Simek K, Chrzanowski TH (1992) Direct and indirect evidence of size-selective grazing on pelagic bacteria by freshwater nanoflagellates. Appl Environ Microbiol 58: $3715-3720$

Simek K, Macek M, Pernthaler J, Psenner R, Straśkrabová V (1996) Can freshwater planktonic ciliates survive on a diet of picoplankton? J Plankton Res 38:597-613

Šmek K, Macek M, Seda J, Vyhnálek V (1990) Possible food chain relationships between bacterioplankton protozoans and cladocerans in a reservoir Int Revue Ges Hydrobiol $75: 583-596$

Responsible Subject Editor: R. Sanders, Philadelphia, Pennsy/vania, USA
Šimek K, Straškrabová V (1992) Bacterioplankton production and protozoan bacterivory in a mesotrophic reservoir. J Plankton Res 14:773-787

Simek K, Vrba J, Hartman P (1994) Size-selective feeding by Cyclidium sp. on bacterioplankton and various sizes of cultured bacteria. FEMS Microb Ecol 14:157-168

Skibbe O (1994) An improved quantitative protargol stain for ciliates and other planktonic protists. Arch Hydrobiol 130 $339-347$

Smits JD, Riemann B (1988) Calculation of cell production from $\left[{ }^{3} \mathrm{H}\right.$ |thymidine incorporation with freshwater bacteria. Appl Environ Microbiol 54:2213-2219

Sorokin YI, Overbeck J (1972) Direct microscopic counting of microorganisms. In: Sorokin YI, Kadota H (eds) Techniques for the assessment of microbial production and decomposition in fresh water. IBP Handbook No. 23, Blackwell Scientific Publications, Oxford, p 44-47

Springmann D (1993) Seasonal succession of heterotrophic nanoflagellates in Lake Constance. Abstract, Workshop of the Plankton Ecology Group on 'Protozooplankton ecology - methods and seasonal successions' Institute for Limnology, Austrian Academy of Sciences, Mondsee, Austria, April 1993

Stockner JG (1988) Phototrophic picoplankton: an overview from marine and freshwater ecosystems. Limnol Oceanogr 33:765-775

Stockner JG, Antia NJ (1986) Algal picoplankton from marine and freshwater ecosystems: a multidisciplinary perspective. Can J Fish Aquat Sci 43:2472-2503

Straškrabová V, Komárková J, Macek M, Seda J, Šimek K, Vrba J, Vyhnálek V (1993) Microbial-algal-crustacean interactions in a reservoir under different fishstock. Arch Hydrobiol Beih Ergebn Limnol 40:209-221

Vaqué D, Pace LM (1992) Grazing on bacteria by flagellates and cladocerans in lakes of contrasting food-web structure. J Plankton Res 14:307-321

Weisse T (1991) The annual cycle of heterotrophic freshwater nanoflagellates: role of bottom-up and top-down control J Plankton Res 13:167-185

Weisse $T$ (1993) Dynamics of autotrophic picoplankton in marine and freshwater ecosysterns. In: Jones JG (ed) Advances in microbial ecology, Vol 13. Plenum Press, New York, p 327-370

Wikner J, Rasssoulzadegan F, Hagström $\AA$ (1990) Periodic bacterivore activity balances bacterial growth in the marine environment. Limnol Oceanogr 35:313-324

Manuscript first received: April 15, 1996

Revised version accepted: October 21, 1996 